\title{
White spotted rose beetle [Oxythyrea funesta (Poda, 1761)] (Coleoptera: Scarabaeidae) - a new threat in agriculture?
}

\author{
Łanocha pobrzęcz [Oxythyrea funesta (Poda, 1761)] \\ (Coleoptera: Scarabaeidae) - nowym zagrożeniem w rolnictwie?
}

\author{
Marek Bunalski ${ }^{1}$, Tomasz Klejdysz ${ }^{2 *}$, Wojciech Kubasik², Paweł Trzciński
}

\section{Summary}

The family of Scarabaeidae has a large group of phytophages, which include economically important plant pests. Climate change is causing new species to appear in our country or formerly marginal pests are gaining in importance. The white spotted rose beetle (Oxythyrea funesta) can be an example of such a species. In recent years, mainly in the east and south of Poland, there have been new locations of this beetle, which is locally very numerous. An example can be the mass appearance of $O$. funesta in Mazowieckie Voivodeship, Makowski County. The beetles were found there in large numbers in rye and triticale crops. In mid-May, they attacked young ears and ate their contents completely, leading to bleaching and withering of the tops of the plants. The damage was of a local nature, but it repeated over the next seasons, clearly increasing in strength. The spread and abundance of this species in Poland should be monitored as it may soon gain economic significance and become a threat to other crops.

Key words: white spotted rose beetle, Oxythyrea funesta, pest, cereals, new threat, Scarabaeidae

\section{Streszczenie}

Rodzina poświętnikowatych (Scarabaeidae) zawiera sporą grupę fitofagów, do których należą ważne gospodarczo szkodniki roślin. Zmiany klimatyczne powodują, że w naszym kraju pojawiają się nowe gatunki lub na znaczeniu zyskują szkodniki do tej pory marginalne. Przykładem takiego gatunku może być łanocha pobrzęcz (Oxythyrea funesta). W ostatnich latach, głównie na wschodzie i południu Polski notuje się nowe stanowiska tego chrząszcza, który miejscowo występuje bardzo licznie. Przykładem może być masowy pojaw łanochy w województwie mazowieckim, powiecie makowskim. Chrząszcze wystąpiły tu masowo w uprawach żyta i pszenżyta. W połowie maja atakowały młode kłosy i całkowicie wyjadały ich zawartość, prowadząc do bielenia i więdnięcia wierzchołków roślin. Uszkodzenia miały charakter lokalny, jednak powtarzały się przez kolejne sezony, wyraźnie przybierając na sile. Rozprzestrzenianie się i liczebność tego gatunku w Polsce powinna być monitorowana, gdyż wkrótce może on nabrać znaczenia ekonomicznego i stać się zagrożeniem również dla innych upraw.

Słowa kluczowe: łanocha pobrzęcz, Oxythyrea funesta, szkodnik, zboża, nowe zagrożenie, Scarabaeidae

\author{
Uniwersytet Przyrodniczy w Poznaniu \\ Katedra Entomologii i Ochrony Środowiska \\ Dąbrowskiego 159, 60-594 Poznań \\ ${ }^{2}$ Instytut Ochrony Roślin - Państwowy Instytut Badawczy \\ Władysława Węgorka 20, 60-318 Poznań \\ *corresponding author: t.klejdysz@iorpib.poznan.pl \\ ORCID: 0000-0002-9660-9771
}


Rodzina poświętnikowatych (Scarabaeidae) obejmuje gatunki o różnych preferencjach pokarmowych, w tym sporą grupę fitofagów. $Z$ niej rekrutują się ważne gospodarczo szkodniki upraw, by wymienić tylko chrabąszcze (Melolontha spp.), guniaki (Amphimallon spp.), ogrodnicę niszczylistkę [Phyllopertha horticola (L.)], czy nałanka kłośca [Chaetopteroplia segetum (Herbst)]. Zmiany klimatyczne zachodzące $\mathrm{w}$ ostatnich dziesięcioleciach mogą być powodem pojawiania się nowych agrofagów lub rozprzestrzeniania się gatunków uważanych dotychczas za marginalne.

Do tej drugiej grupy można z pewnością zaliczyć łanochę pobrzęcz (Oxythyrea funesta). Jeszcze na początku lat 80. XX wieku dominował pogląd, że gatunek ten wycofał się z obszaru Polski, bowiem w okresie powojennym nie był nigdzie notowany (Burakowski i wsp. 1983). Sytuacja zaczęła zmieniać się pod koniec XX wieku, gdy pojawiły się pierwsze informacje pochodzące z południowo-wschodniej części kraju (Szwałko 1989). W ostatnim dziesięcioleciu gatunek był już obserwowany w całym pasie wschodnim, docierając na północy do Puszczy Białowieskiej (Taszakowski i wsp. 2014) i kolonizując cały pas południowej Polski.

Wszystkie te doniesienia miały jednak charakter faunistyczny, a obserwowane liczebności były stosunkowo niewielkie. W ostatnich kilku latach sytuacja uległa jednak diametralnej zmianie, o czym świadczą liczne pojawy tego gatunku w 2017 i 2018 roku w powiecie makowskim, w województwie mazowieckim. Chrząszcze wystąpiły tam masowo w uprawach żyta i pszenżyta niszcząc wiele roślin. $\mathrm{W}$ połowie maja atakowały młode kłosy i całkowicie wyjadały ich zawartość prowadząc do bielenia i więdnięcia wierzchołków roślin (fot. 1). Uszkodzenia miały wprawdzie charakter lokalny, niemniej powtarzały się przez kolejne sezony, wyraźnie przybierając na sile.

Objawy żerowania łanochy przypominają te, które powoduje nałanek. $Z$ uwagi na podobieństwa w bionomii obydwu gatunków można przypuszczać, że szkody wyrządzane przez pędraki łanochy mogą być również duże, choć nie było to do tej pory obiektem badań w Polsce.

Biorąc pod uwagę szybkie rozprzestrzenianie się łanochy i stwierdzenie jej obecności w Wielkopolsce (Bunalski i wsp. 2019), wydaje się koniecznym podjęcie badań nad szkodliwością w warunkach lokalnych oraz opracowaniem metod ograniczania jej liczebności, gdyż owad ten wyraźnie powiększa swój areał występowania i liczebność, również poza terenem Polski. W ostatnich dekadach wykryty został w krajach nadbałtyckich: Litwa, Łotwa i Estonia, a nawet w okolicach Sankt Petersburga w Rosji (Kadej i wsp. 2013). Chrząszcze łanochy pobrzęcz powodują też uszkodzenia kwiatów kilku gatunków roślin ozdobnych oraz sadowniczych, m.in. na Węgrzech, gdzie stosuje się pułapki z atraktantem do ich odłowu (Vuts i wsp. 2008). Niewykluczone, że wkrótce gatunek ten może powodować podobne uszkodzenia roślin również w Polsce.

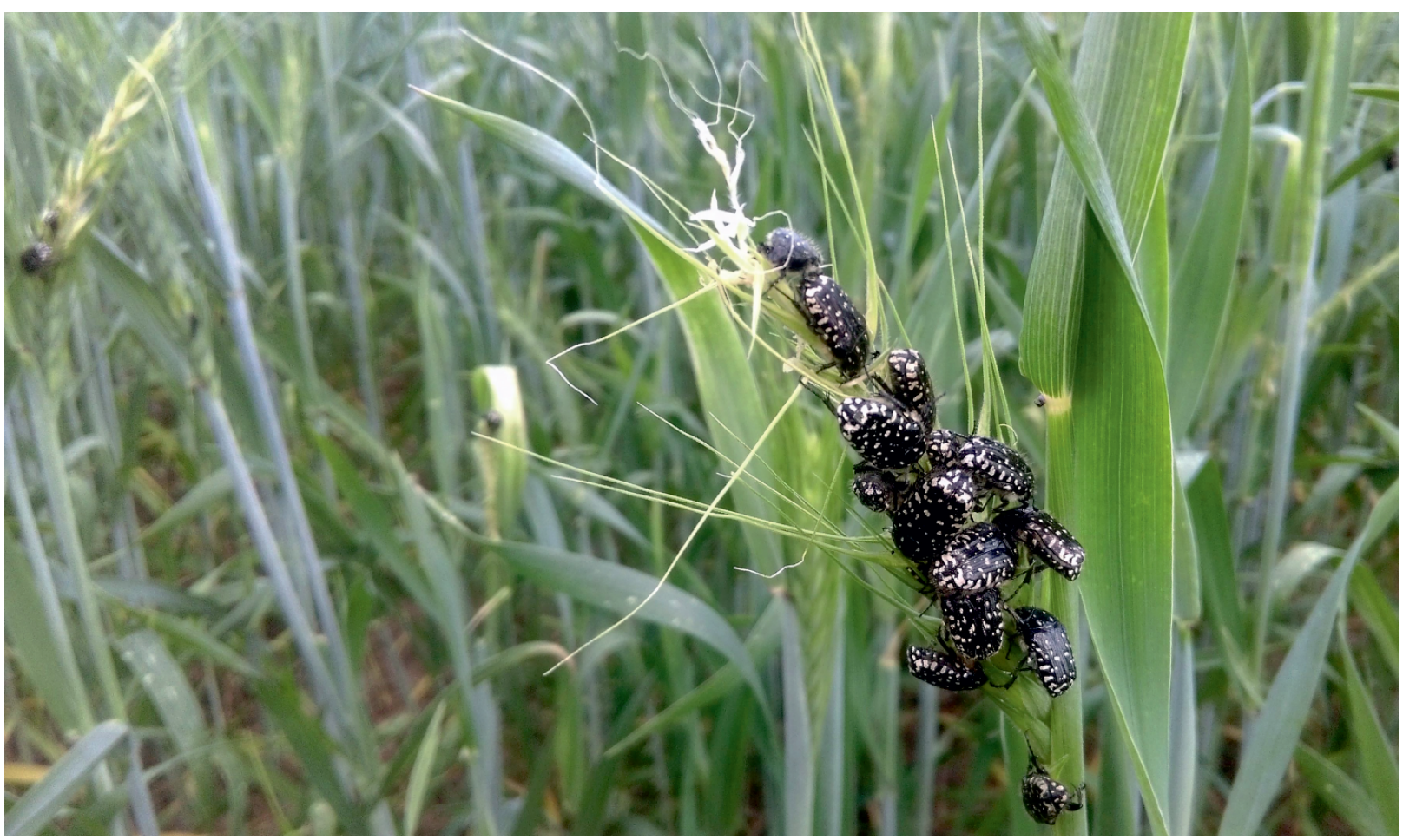

Fot. 1. Chrząszcze łanochy pobrzęcz (Oxythyrea funesta) wyjadające ziarniaki (fot. M. Modzelewski)

Fig. 1. White spotted rose beetle (Oxythyrea funesta) eating cereal grains (photo M. Modzelewski) 


\section{Literatura / References}

Bunalski M., Konwerski Sz., Przewoźny M. 2019. Materiały do poznania rozmieszczenia chrząszczy (Coleoptera) Zachodniej Polski. Część 17. Scarabaeidae pleurosticti - uzupełnienia i korekty. Wiadomości Entomologiczne 38 (2): 69-77.

Burakowski B., Mroczkowski M., Stefańska J. 1983. Chrząszcze - Coleoptera. Scarabaeoidea, Dascilloidea, Byrrhoidea i Parnoidea. Katalog Fauny Polski 23 (9): 1-294.

Kadej M., Zając K., Smolis A., Malkiewicz A., Tarnawski D., Kania J., Gil R., Myśków E., Sarnowski J., Tyszecka K., Józefczuk J., Rodziewicz M. 2013. Nowe dane o rozsiedleniu wybranych gatunków poświętnikowatych (Insecta: Coleoptera: Scarabaeidae) w Polsce południowo-zachodniej. [New data on the distribution of selected species of scarab beetles (Insecta: Coleoptera: Scarabaeidae) in south-western Poland]. Przyroda Sudetów 16: 95-114.

Szwałko P. 1989. Występowanie Oxythyrea funesta (Poda, 1761) (Coleoptera, Scarabaeidae) w Polsce. Przegląd Zoologiczny 38 (1): $83-87$.

Taszakowski A., Szczepański W.T., Baran B., Morawski M. 2014. Nowe stanowiska Oxythyrea funesta (Poda, 1761) (Coleoptera: Scarabaeidae) w Polsce. [New localities of Oxythyrea funesta (Poda, 1761) (Coleoptera: Scarabaeidae) in Poland]. Acta Entomologica Silesiana 22 (online 004): $1-2$.

Vuts J., Imrei Z., Tóth M. 2008. Development of an attractant-baited trap for Oxythyrea funesta Poda (Coleoptera: Scarabaeidae, Cetoniinae). Zeitschrift für Naturforschung C 63 (9-10): 761-768. DOI: 10.1515/znc-2008-9-1023 